\title{
THE IMPACT OF THE INSTITUTIONAL ENVIRONMENT ON THE DEVELOPMENT OF THE RURAL ECONOMY IN THE BELGOROD REGION OF RUSSIA
}

\author{
Andrei Dorofeev ${ }^{1}$, Sergei Sazonov ${ }^{1}$, Wim Heijman² \\ ${ }^{1}$ Belgorod State Agricultural Academy named after V.Gorin, Belgorod, Russia \\ ${ }^{2}$ Wageningen University, the Netherlands, Wageningen
}

This article deals with the problems in the development of agriculture in Russia caused by an imperfect institutional environment. The characteristics of institutional conditions and their influence on the development of agriculture is discussed. The main institutional changes which have taken place in Russia over the past 20 years are described, including the ownership of the means of production, commodity-money relations, access to and distribution of profits and competition. The main body of the article presents an analysis of the development of agriculture in the Belgorod region in relation to the status of the institutional environment.

Keywords: institutions, institutional change, food security, investments, specialization, gross wages, collection

\section{Introduction}

Over the last 20 years, institutional transformation of the Russian economy had negative effects on the distribution of income, unemployment, poverty and social differentiation of income between agriculture and non-agriculture economy, which caused immense social and economic problems, particularly in terms of the rural economy. Indeed, total privatization, concentration of property in the form of vertical integrated enterprises, and disparities in the prices of agricultural and industrial products had a deep structural impact.

The aim of the paper is therefore to try to identify the winners and losers of institutional transformations in the Russian agricultural economy. Specifically, we investigate the impact of institutional transformation on the wages of individual agricultural workers.

This paper concerns itself with one aspect of institutional transformation, namely the industrialization and concentration of agricultural production; it provides a detailed estimation as to the impact of the concentration of agricultural production on wages for various groups of agricultural producers.

A key feature of today's industrialization process in Russian agriculture is ever-increasing production, resulting in concentration and manifesting itself in a fast growing share of large agricultural enterprises.

Methods of this paper briefly discusses the theoretical background and the expected impact of the institutional environment on the relationship between the economic subjects. Results and discussion describes the empirical approach, namely the measurement of outsourcing and data. The final section offers a brief conclusion.

\section{Methods}

\section{Theoretical background and the expected impact of the institutional environment on the relationship between the economic subjects}

Modern agriculture does not fully implement the economical and long-term private interests of agricultural producers. A poor institutional environment has effects on the agro-industrial complex, with the consequence of a disparity in the prices of industrial and agricultural products, the low profitability of many agricultural producers, and the outflow of resources in other industries. Meanwhile, the actual parameters of Russia's food security are significantly lower than envisaged in the policy the Russian Federation's government.

In this context, reacting to the existing and future institutional context through agrarian research on the socio-economic system of the region is very important.

According to North, institutions are the "rules of the game" in a society, or, to put it more formally, a man-made restrictive framework that organizes relationships between people. Hence, they ask the motivations of human interaction - whether in politics, the social sphere or economics. Institutional changes determine how societies evolve over time, and are thus key to understanding the historical changes (North, 1990).

Brousseau, developing North's ideas, notes that there is a clear consensus that people establish institutions. Some of the "highest level" institutions limit games, according to which "lower level" institutions are purposed (Brousseau, Garrouste and Raynaud, 2011).

To gain a meaningful understanding of institutions as a system, it is necessary to understand the interaction between the different institutions as well as to understand the changes within institutions.

Dulbecco believes that institutional structure, which currently prevails in the economy, can help or hinder the process of liberalization, the capacity to integrate new members.

Each author has their own examples of the impact on the economy of agricultural institutions, but all come to the same conclusion, namely that their role is very significant.

The authors of this paper see institutions as being the conditions that determine the behavior of economic actors. Institutions, like any other economic category, have the property of variability.

According to Brousseau, nothing guarantees that the social system will evolve towards greater effectiveness. We must therefore acknowledge that competitive selection among institutional solutions allows us to organize management structure: agents should therefore choose wisely. Data examined the institutional problems of high loan rates for agriculture in India. Loan problems cause more difficulty for small-scale farmers (including marginal farmers) and other vulnerable groups and (landless) rural communities, who often don't have the merchandise, creditworthy projects or political influence 
to gain access to formal sources of credit. Despite the government's position in the form of priority sector lending, both the government and formal lenders are often unwilling to lend to large number of borrowers who are landless or belong to smallholder farming communities (Brousseau, Garrouste and Raynaud, 2011).

Chang shows that the foundations of institutional theory have a very problematic understanding of the relationship between institutions and economic development. First, the institutions are more or less ignored in terms of the impact of economic development on institutions, research focusing solely on how institutions affect development. Secondly, the institutions that provide greater freedom for business and enhance the protection of private property rights have resulted in higher growth. Thirdly, the basis of institutional theory mistakenly considers the relationship between institutions and economic development to be linear and uniform across time and space (Chang and Evans, 2005).

In agricultural economics, inequality of income, imperfections in market factors and the delay in making structural changes in agriculture have been left unconsidered for a long time. The transition to a market economy in Central and Eastern Europe has increased the demand for a suitable theoretical basis for analysing organisational issues, not only in agriculture but also in rural areas as a whole.

Eaton believes that specific institutional arrangements serve primarily to ensure a more efficient exchange of goods and services. For example, a business with employees has the advantage of allowing the owner or Manager to save on transaction costs by avoiding having to constantly re-enter into contracts (agreements) on the provision of their skills. In addition, the use of agroindustrial integration can reduce the costs for farmers and buyers in locating and providing products compared to using a "spot" market. Most importantly, these measures will help reduce the uncertainty which is also part of the transaction costs (Brousseau, Garrouste and Raynaud, 2011).

Kokorev highlights the following as being the most important, institutions in Russia which are considered to be flawed:
$\square$ government development institutions,
$\square$ corporate governance institutions,
$\square$ financial market institutions,
$\square$ small business support institutions,
$\square$ institutions for the protection of property rights (Kokorev, 2008).

In our view, the overall institutional environment can be classified into the following groups:

1. Organizational factors. The impact of regional authorities characterizes the structure of investment sources in agriculture. The State has direct and indirect participation in the investment process, where direct participation means investing in the public sector and indirect participation means providing loans and subsidies (and other forms of economic control?) through a policy of economic regulation.
2. Economic factors. Among various economic factors, a redistribution of income between different spheres of economic activity has the greatest impact on the state of the agricultural organizations.

3. Legal and regulatory conditions, generated at the federal level, allow the creation of various forms of agricultural organizations.

Legal regulation of relations in the sphere of agriculture and sustainable development of rural areas are covered by the "Federal Law of agriculture development", other federal laws and regulatory legal acts of the Russian Federation, laws and other normative legal acts of the constituent entities of the Russian Federation and normative legal acts of local self-government bodies.

4. Economic relations regulated mainly outside the economic structure include the interaction between the authorities and the trade unions (associations), as well as the interaction between economic agents that can change the State of competition in product markets.

\section{Results and discussion}

We used the following methods:

a) statistical observations - collection of information on agricultural enterprises;

b) statistical hypothesis testing - comparative economic evaluation of the main types of agricultural organisations;

c) abstract logical clarification of each institution's definition and institutional conditions.

The major institutional changes that have taken place in Russia in the last 20 years (Table 1$)$.

These institutional changes require in-depth analysis. First of all, therefore, it is important to trace the impact of institutional change on the agrarian economic system of each separate region. In our study, the chosen region is Belgorod region, which is located in the Central Federal District of the Russian Federation (Figure 1).

The surface area is 27.1 thousand $\mathrm{km}^{2}$ and its length measures around $190 \mathrm{~km}$ from North to South, and around $270 \mathrm{~km}$ from East to West.

The climate is continental with a relatively mild winter with snowfalls, thaws and long summers. The average annual temperature varies from +5.4 degrees +6.7 degrees in the North to the South-East.

Belgorod region is a highly developed industrial and agricultural region, whose economy relies on the enormous wealth of mineral resources and unique black soils.

The positive developments in the economy of the region in recent years and measures taken to improve the demographic situation have led to its recovery: there is a rising birth rate and decreasing mortality and attrition rates, and a positive migration balance remains.

Today, the Belgorod area remains one of the few regions of both the Russian Federation and the Central Federal District (along with Moscow and the Moscow region)in which the population continues to grow.

Table 1 The main institutional changes in Russia

\begin{tabular}{|l|c|c|}
\hline \multirow{2}{*}{ Institute } & \multicolumn{2}{|c}{ State of the Institute } \\
\cline { 2 - 3 } & \multicolumn{1}{|c}{ Before the reform of 1991-1992 } & \\
\hline Ownership of the means of production & - state ownership & $\bullet$ private ownership predominates \\
\hline Commodity-money relations & - was largely dominated by State bodies & $\bullet$ partially regulated by the public authorities. The main regulator is the market. \\
\hline Profit-sharing opportunities & - profit-sharing opportunities are limited $1991-1992$ \\
\hline Competition & - no competition & $\bullet$ earning and distribution of profit are the main features of commercial organizations \\
\hline
\end{tabular}




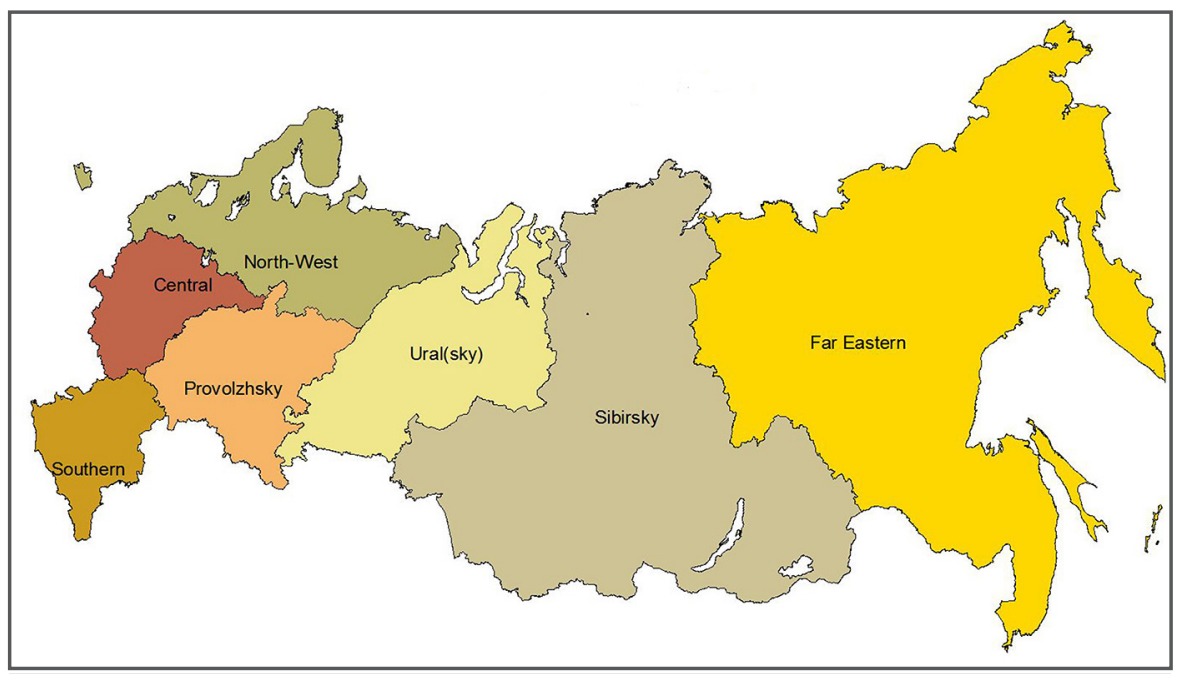

Figure 1 Federal Districts of RussiaBelgorod is a region of the Russian Federation, and is part of the Central Chernozem (trsl. - "black soil") economic region and the Central Federal District of the Russian Federation

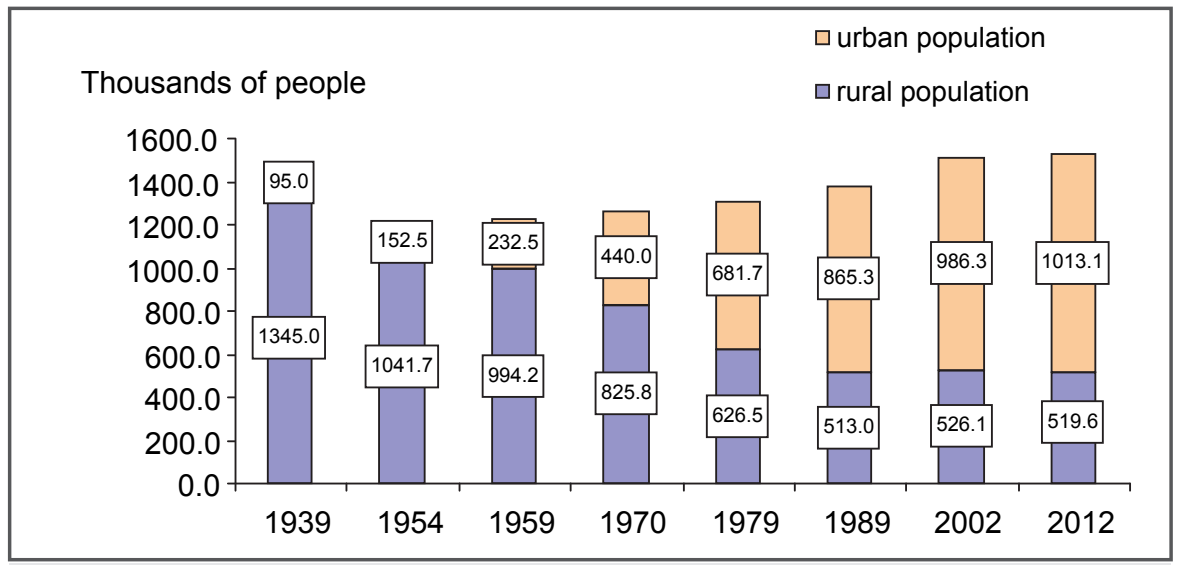

Figure 2 Dynamics of urban and rural populations in the Belgorod region

According to the preliminary results of the all-Russian population census, the population was 1532.7 thousand people in 2012, and has grown over the last intercensal period by 21.1 thousand people, or 1.4 percent.

On the other hand, despite the growth of the total population, there has been a strong trend for the rural population to migrate to the city, where the wages are higher. In 2012 the urban population grew by 27.5 thousand people, or $2.8 \%$ up to 519,6 thousand (34\%). The shortage of skilled professionals and workers in the countryside, especially in the context of the WTO, may have an irreparable impact on agriculture and food security.

To assess the status of food security, the proportion of domestic agricultural and fish products and foodstuffs is determined in the total volume of commodity resources of related products on the internal market (taking into account the transition stocks) with the following thresholds: grain is not less than $95 \%$; sugar is not less than $80 \%$; vegetable oil is not less than $80 \%$; meat and meat products (meat)-not less than $85 \%$; milk and dairy products (milk)-not less than 90\%; potatoes-not less than $95 \%$.

The Government of the Belgorod region considers regional agriculture as a zone of advanced growth despite the fact that the sustainability of agricultural products has been relatively high for a long time (Table 2).

The level of self-sufficiency in agricultural products is determined by dividing the total output by the domestic consumption. Thus, in the Belgorod region, 5.5 times more meat is produced than consumed, this being a result of the regional division of labor which allows making the best use of the existing potential of regions.

\section{The level of development of individual branches of agriculture is determined by the amount of investment in these branches}

In the process of implementation of regional programs with the active control exposure and support from the executive authorities in the area, poultry, pig and dairy farming have formed and tend to develop into clusters (Socio-economic development strategy of Belgorod region until, 2025) indicated by information on investment activities in Belgorod region (Table 3).

Impact of regional authorities that characterizes the structure of sources of investment in agriculture (Table 4). Most of the investments are from funds dominated by bank loans.

In the classic model of a market economy, the overwhelming proportion of real investments are private investments. The State is also involved in the investment process, both directly, by investing in the public sector, and indirectly, by providing loans, subsidies and through a policy of economic regulation. The bulk of public investment goes into the industry's infrastructure, the development of which is necessary for

Table 2 The level of self-sufficiency in basic agricultural commodities in Belgorod region in \%

\begin{tabular}{|l|c|c|c|c|c|c|c|}
\hline Types of products & $\mathbf{2 0 0 6}$ & $\mathbf{2 0 0 7}$ & $\mathbf{2 0 0 8}$ & $\mathbf{2 0 0 9}$ & $\mathbf{2 0 1 0}$ & $\mathbf{2 0 1 1}$ & $\mathbf{2 0 1 2}$ \\
\hline Grain & 110.8 & 105.3 & 84.7 & 102.6 & 129.5 & 77.5 & 37.4 \\
\hline Meat & 154.0 & 185.9 & 229.2 & 296.0 & 400.3 & 491.3 & 553.3 \\
\hline Milk products & 135.0 & 129.8 & 122.6 & 123.9 & 127.3 & 127.7 & 124.0 \\
\hline Eggs & 145.7 & 148.1 & 160.4 & 159.3 & 177.0 & 158.7 & 158.1 \\
\hline Potatoes & 121.1 & 120.6 & 94.1 & 128.4 & 106.0 & 99.9 & 61.1 \\
\hline Vegetables and edible gourds & 109.3 & 109.7 & 103.7 & 97.3 & 95.0 & 91.6 & 79.6 \\
\hline
\end{tabular}

Source: Agriculture of the Belgorod Region, 2013 
Table 3 Fixed capital investments for agricultural development and commissioning of production facilities in Belgorod region

\begin{tabular}{|c|c|c|c|c|c|c|c|}
\hline & 2006 & 2007 & 2008 & 2009 & 2010 & 2011 & 2012 \\
\hline \multicolumn{8}{|c|}{ Fixed capital investments for the development of agriculture (in current prices, excluding VAT } \\
\hline$\%$ of the total volume & 21.2 & 21.4 & 34.6 & 39.6 & 37.5 & 34.9 & 26.3 \\
\hline \multicolumn{8}{|c|}{ Investments in fixed capital commissioning production capacity due to new construction, expansion and renovation } \\
\hline \multicolumn{8}{|l|}{ The livestock premises, thous. seats: } \\
\hline - cattle & 2.7 & 2.80 & 4.35 & 13.95 & 3.54 & 11.5 & 0.4 \\
\hline - pigs & 3.5 & 8.7 & 131.1 & 235.0 & 389.1 & 477.3 & 118.9 \\
\hline \multicolumn{8}{|l|}{ Poultry: } \\
\hline - beef, mln. heads of meat / poultry per year & - & - & 30.76 & 55.51 & 67.69 & - & 87.6 \\
\hline - beef, tons of meat per shift & - & - & - & 0.6 & 189.0 & - & - \\
\hline - laying hens, thous. & 290.0 & 583.0 & 339.0 & 547.0 & 633.0 & 950.0 & - \\
\hline - feed enterprise, tons of fodder a day & 240.0 & 9.0 & 783.82 & 1903.0 & 1212.0 & 665.0 & - \\
\hline
\end{tabular}

Source: Agriculture of the Belgorod Region, 2013

Table 4 The distribution of investments in fixed capital aimed at the development of agriculture, by source of funding in \% of total

\begin{tabular}{|c|c|c|c|c|c|c|c|}
\hline & 2006 & 2007 & 2008 & 2009 & 2010 & 2011 & 2012 \\
\hline Fixed capital investments for agricultural development-total & 100 & 100 & 100 & 100 & 100 & 100 & 100 \\
\hline - organizations' own funds & 29.9 & 24.9 & 15.8 & 12,1 & 16.1 & 27.3 & 29.3 \\
\hline - raised funds within organizations' budget & 70.1 & 75.1 & 84.2 & 87,9 & 83.9 & 72.7 & 70.7 \\
\hline The federal budget & 0.5 & 0.6 & 1.6 & 1,6 & 2.1 & 3.3 & 0.2 \\
\hline \multicolumn{8}{|l|}{ Including from: } \\
\hline - the budgets of the constituent & 0.4 & 0.3 & 0.4 & 0.7 & 1,2 & 2.1 & - \\
\hline - entities of the Russian Federation & 0.1 & 0.1 & 1.2 & 0.9 & 0.8 & 1.2 & 0.2 \\
\hline
\end{tabular}

Source: Agriculture of the Belgorod Region, 2013

normal social reproduction (science, education, health, environment, energy, transport and communication system, etc.).

\section{Through increased production and better provisions in competition, major agricultural organizations freeze out the smaller ones from the market. This leads to bankruptcy or the consolidation of small enterprises (Table 5)}

The results in Table 5 show that the output returns on 1 ha and 1 worker pay in larger enterprises are higher than that of small enterprises. In this regard, their unequal bargaining power results in the loss of profits for small businesses. The figures in the table clearly illustrate the situation. On the other hand, each study group has a margin of error. Therefore, on the basis of the data in Table 5 , it is necessary to determine the materiality of the difference between the compared groups.

Table 5 The grouping of agricultural enterprises of various organizationallegal forms in the Belgorod region by the average annual number of employees in all industries for the year 2012

\begin{tabular}{|c|c|c|c|}
\hline & Group by size & Total output for enterprise in rub / year & Salary total in rub \\
\hline 1 & $<50$ & 17100 & 9060 \\
\hline 2 & $51-100$ & 60100 & 10114 \\
\hline 3 & $101-200$ & 71800 & 11578 \\
\hline 4 & $201-500$ & 71400 & 11980 \\
\hline 5 & $>500$ & 19470 & 15915 \\
\hline
\end{tabular}

The method used in this study to find the presence or absence of significant differences in efficacy consists of the application of standard statistical procedures in order to test a medium hypothesis.

Theory of statistics causes two kinds of hypotheses on the average values:

$\square$ the hypothesis of equality of the mean established and the regulation;

$\square$ the hypothesis of equality of the mean value of two aggregates features.

The hypothesis of equality of the mean value of two aggregates features is often set to test the impact of any factor on average.

As a criterion for verifying this hypothesis, $t$-statistics is adopted, the actual value of which $\left(t_{\text {fact }}\right)$ according to the results of a sample survey is calculated by the formula:

$$
t_{\text {fact }}=\frac{\left|\bar{x}_{1}-\bar{x}_{2}\right| \sqrt{n_{1}+n_{2}-2} \sqrt{n_{1} n_{2}}}{\sqrt{n_{1} \sigma_{1}^{2}+n_{2} \dot{o}_{2}^{2}} \sqrt{n_{1}+n_{2}}}
$$

where:

$x_{1}$ and $x_{2}$ - the mean value of the two aggregates

and $\quad-$ dispersion in general aggregates

$n_{1}$ and $n_{2}$ - quantity of aggregates

Comparing the actual value of the $t$-statistic with a table (on the basis of the critical value $t$ Student criterion) with the specified level of significance, it can be concluded whether it is necessary to agree with the hypothesis or reject it. 
If the result of the study of the actual value of the $t$-statistic is less than in the table, i.e. $t_{\text {fact }}<t_{\text {tabl }}$, then the hypothesis is rejected. Otherwise, a null hypothesis should be rejected. Hypothesis testing on the materiality of the difference between the mean values for groups of enterprises was carried out for the year 2012 according to the operational information of the Department of Agrarian and Industrial Complex of the Belgorod region.

For example, verification of hypotheses about the materiality of the difference between the average profit yield per person in enterprises with fewer than 500 employees and enterprises with 201-500 employees in 2012 has shown that the difference between groups of agricultural enterprises is statistically significant: the profits in enterprises with more than 500 employees are substantially higher in 2012 than in enterprises with 201-500 employees (Table 6).

Among the compared groups, other groups have significant differences (listed below). A summary of materiality test results of the differences between the compared groups of the agricultural organizations are presented in Table 7.

Table 7 shows that groups of enterprises with more than 500 employees have significantly higher returns on output per employee compared to all other groups studied.

As a result, the number of small businesses is becoming smaller and smaller. Some businesses face bankruptcy, while others merge together to form larger ones.

The number of both small and large agricultural enterprises is declining. If the number of large enterprises decreases at an average rate of

Table 6 Verification of statistical hypotheses about the difference between the average profit yield per person between groups of enterprises with more than 500 employees and groups with 201-500 employees

\begin{tabular}{|l|c|c|}
\hline \multirow{2}{*}{ Indicators } & \multicolumn{2}{|c|}{ Group by size } \\
\cline { 2 - 3 } & more than $\mathbf{5 0 0}$ & $201-500$ \\
\hline Number of organisations & 10 & 14 \\
\hline Average profit yield for 1 person. rub & 195 & 71 \\
\hline The variance of output came to 1 person & 19783 & 4790 \\
\hline Actual value of the Student & \multicolumn{2}{|c|}{$t_{\text {fact }}=2.71$} \\
\hline The $t$-test-valued of the Student & \multicolumn{3}{|c|}{$t_{05}=2.06$} \\
\hline
\end{tabular}

Conclusion: the null hypothesis is rejected ( $t$-fakt $>t 05$ ). With a probability of 0.95 , it could be argued that in 2012 the average return on output per employee is higher in the enterprises employing more than 500 employees

Table 7 Significant differences in the output per worker among groups of agricultural enterprises of Belgorod region for the year 2012

\begin{tabular}{|l|c|c|}
\hline $\begin{array}{c}\text { The compared groups of enterprises } \\
\text { by number of employees } \\
\text { more than } 500 / 201-500\end{array}$ & $\begin{array}{c}\text { Type of benefit in accordance } \\
\text { with Student } t \text {-test }\end{array}$ \\
\hline 1 & more than 500 \\
\hline 2 & more than $500 / 101-200$ & more than 500 \\
\hline 3 & more than $500 / 51-100$ & more than 500 \\
\hline 4 & more than $500 /$ up to 50 & more than 500 \\
\hline 5 & $201-500 / 101-200$ & no significant difference \\
\hline 6 & $201-500 / 51-100$ & no significant difference \\
\hline 7 & $201-500 /$ up to 50 & no significant difference \\
\hline 8 & $101-200 / 51-100$ & no significant difference \\
\hline 9 & $101-200 /$ up to 50 & no significant difference \\
\hline 10 & $51-100 /$ up t0 50 & no significant difference \\
\hline
\end{tabular}

Table 8 The average size of the sown area per 1 agricultural enterprise of Belgorod region in ha

\begin{tabular}{|l|c|c|}
\hline Year & Large agricultural enterprises & Small agricultural enterprises \\
\hline 2002 & 3290 & 36 \\
\hline 2003 & 2819 & 36 \\
\hline 2004 & 2374 & 42 \\
\hline 2005 & 3263 & 41 \\
\hline 2006 & 3313 & 42 \\
\hline 2007 & 3153 & 50 \\
\hline 2008 & 3334 & 64 \\
\hline 2009 & 3395 & 68 \\
\hline 2010 & 3789 & 74 \\
\hline 2011 & 5406 & 87 \\
\hline 2012 & 5172 & 80 \\
\hline
\end{tabular}

Source: Agriculture of the Belgorod Region, 2013

24 enterprises per year, the number of small-enterprises decreases to 41 per year, almost double the rate.

A reduction in the number of agricultural enterprises is the consequence of the process of economic concentration, developing in the Belgorod region, mostly in the form of agro-industrial integration (Table 8).

The average size of the sown area per one large agricultural enterprise increased by 1.6 times.

Further, the average size of the acreage of small agricultural enterprises increased by 2.2 times. However, the absolute size of a single land use in small enterprises is most cases lower than in large ones.

\section{High price disparities between agricultural products (raw material for processing) and finished products after processing}

Among the various economic factors, the greatest impact on the state of the agricultural organizations is caused by a redistribution of income between economic activities. Economic concentration in agriculture contributes to a greater benefit, which promotes the concentration of commercial and industrial capital. This is a nationwide problem, as evidenced by various facts shown in Table 9.

For example, in the structure of the retail prices of basic foods, the share of agriculture (the cost of the raw material) is less than the overall share of the processing industry and trade (Table 9). In the structure of the retail prices of wheat flour, the share of trade (turnover of treatment) is 1.9 times more than the cost of the grain used to produce the flour. This ratio can only be the result of the application of different market powers.

Receiving insufficient profit from the sale of their products, agricultural organizations lack funds to buy the necessary level of logistical resources and pay higher wages. As a result, the average wage of agricultural workers is only half that of the Russian average as a whole (Table 10).

The highest wage is in financial activity and mining. In 2012, the highest was 4.8 times higher than the wage of agricultural workers, and the second highest was 3.8 times higher. This situation leads to an outflow of skilled labour from agriculture, despite the fact that agricultural production is a more important activity for the economy than banking.

Redistribution of added value in agriculture occurs by forestalling the growth of prices for industrial products. This is illustrated in Figure 3, and the results of leveling the series are presented in this figure. 
Table 9 The structure of $1 \mathrm{~kg}$ of food retail prices in 2012

\begin{tabular}{|c|c|c|c|c|c|c|}
\hline & \multicolumn{2}{|r|}{ Wheat } & \multicolumn{2}{|c|}{ Sugar from sugar beet } & \multicolumn{2}{|c|}{ Pasteurized milk } \\
\hline & rub & in $\%$ to the total price & rub & in $\%$ to the total price & rub & in $\%$ to the total price \\
\hline $\begin{array}{l}\text { Raw materials and basic materials, minus return flows of } \\
\text { wastes, incidental and related products }\end{array}$ & 5.4 & 29.0 & 12.1 & 35.5 & 11.5 & 42.1 \\
\hline Manufacturing expenses & 1.8 & 9.7 & 5.2 & 15.3 & 5.6 & 20.5 \\
\hline Selling expenses & 0.3 & 1.6 & 0.4 & 1.2 & 1.4 & 5.1 \\
\hline Full unit cost of production & 7.5 & 40.3 & 17.7 & 52.0 & 18.5 & 67.7 \\
\hline Profits of enterprises engaged in food selling & 0.2 & 1.1 & 3.7 & 10.9 & 0.6 & 2.2 \\
\hline Price excluding VAT and other taxes selling & 7.7 & 41.4 & 21.4 & 62.9 & 19.1 & 69.9 \\
\hline Price with VAT and other taxes & 8.5 & 45.7 & 23.5 & 69.1 & 21.0 & 76.9 \\
\hline Turnover areas & 10.1 & 54.3 & 10.6 & 30.9 & 6.2 & 22.7 \\
\hline
\end{tabular}

Source: Russia in figures, 2013

Table 10 Average monthly nominal accrued wages of employees by economic activity in thous. rub

\begin{tabular}{|c|c|c|c|c|c|c|c|c|}
\hline Economic activities & 2000 & 2006 & 2007 & 2008 & 2009 & 2010 & 2011 & 2012 \\
\hline Total & 2.2 & 6.7 & 8.6 & 10.6 & 13.6 & 17.3 & 18.8 & 21.2 \\
\hline Agriculture, hunting and forestry & 0.99 & 3.0 & 3.6 & 4.6 & 6.1 & 8.5 & 9.5 & 10.6 \\
\hline Fishing and aquaculture & 2.9 & 7.1 & 10.2 & 12.3 & 14.8 & 19.5 & 23.3 & 23.5 \\
\hline Mining & 5.9 & 16.8 & 19.7 & 23.2 & 28.1 & 33.2 & 35.2 & 39.9 \\
\hline Distribution of electric energy gas and water supply & 3.2 & 8.6 & 10.6 & 12.8 & 15.6 & 19.1 & 21.7 & 24.3 \\
\hline Construction & 2.6 & 7.3 & 9.0 & 10.9 & 14.3 & 18.6 & 18.3 & 22.1 \\
\hline Wholesale and retail trade & 1.6 & 4.9 & 6.6 & 8.2 & 11.5 & 14.9 & 15.9 & 19.4 \\
\hline Hotels and restaurants & 1.6 & 4.7 & 6.0 & 7.5 & 9.3 & 11.5 & 12.7 & 14.3 \\
\hline Transport and connection & 3.2 & 9.3 & 11.4 & 13.4 & 16.4 & 20.8 & 22.5 & 25.8 \\
\hline Financing & 5.2 & 17.4 & 22.5 & 27.9 & 34.9 & 41.9 & 42.4 & 50.6 \\
\hline Real estate operations, renting and provision of services & 2.5 & 7.8 & 10.2 & 12.8 & 16.6 & 21.3 & 22.6 & 26.0 \\
\hline Public administration and military security ensuring; Social Security & 2.7 & 7.9 & 11.0 & 13.5 & 16.9 & 21.3 & 23.7 & 25.1 \\
\hline Education & 1.2 & 4.2 & 5.4 & 7.0 & 8.8 & 11.3 & 13.3 & 14.1 \\
\hline Public health and social work services & 1.3 & 4.6 & 5.9 & 8.1 & 10.0 & 13.1 & 14.9 & 15.7 \\
\hline Other community, social and personal services & 1.6 & 4.8 & 6.3 & 8.0 & 10.4 & 13.5 & 15.7 & 16.2 \\
\hline
\end{tabular}

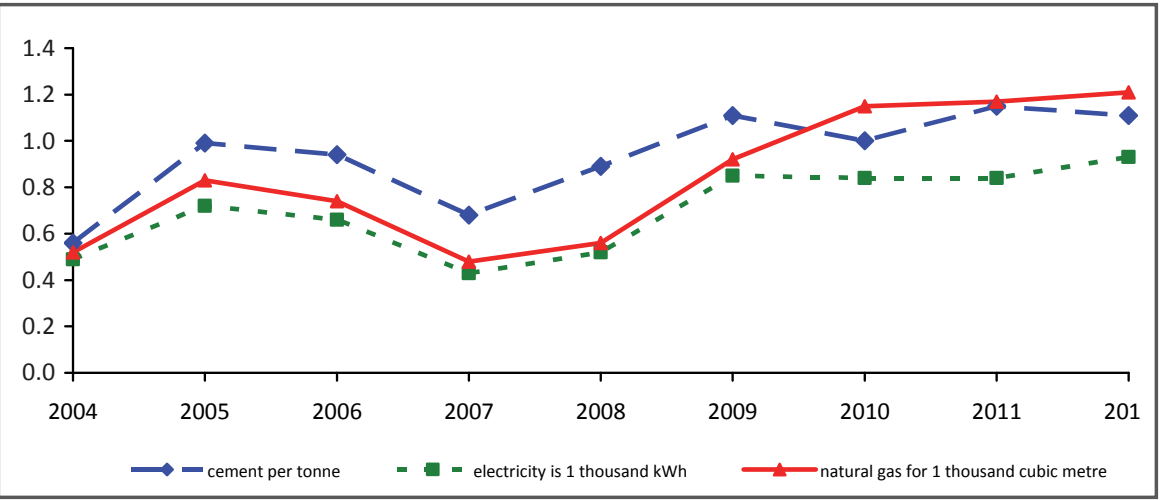

Figure 3 Dynamics of prices for industrial products
Mathematical aligns of time series showed that during 2004-2012, the average gain of "prices" of 1 ton of cement is $54 \mathrm{~kg}$ of grain per year, 1 thousand $\mathrm{kW}$ of energy $-42 \mathrm{~kg}$, 1 thousand cubic meters of gas $-68 \mathrm{~kg}$ of winter wheat grain.

Thus, the analysis of the impact of institutional conditions on the development of agriculture in the region suggests that their current status does not allow full implementation of public and long-term interests for the majority of private agricultural producers. It seems that the steps taken by the Federal and regional authorities in recent years have focused mainly on the neutralization of unwanted reactions of economic entities and the adverse effects 
of agricultural reform, but not on the creation of long-lasting effective institutional development conditions for the agrarian sector of the economy.

Legal regulation of relations in the sphere of agriculture and sustainable development of rural areas is covered by the Federal Law of agriculture development, as well as by other federal laws and regulatory legal acts of the Russian Federation, laws and other normative legal acts of the constituent entities of the Russian Federation, and normative legal acts of local selfgovernment bodies.

The document defining the objectives and main directions of agriculture development and the markets management in the medium term, as well as financial security and mechanisms for the implementation of activities, is the State Program for Agriculture Development and the Management of Agricultural Markets, Raw Materials and Food. The State Program has been approved by the Government of the Russian Federation for a period of five years. It contains the main indicators of and predictions for agricultural development, goals, objectives, performance indicators and expenditure commitments, including allocation of financial resources and the challenges ahead.

The goals of the Program are: sustainable development of rural territories, increasing employment and living standards of the rural population; enhancing the competitiveness of agricultural products; implementing preservation and reproduction in agricultural production, land and other natural resources.

For dynamics in these common areas is supposed to be achieved by the same general objectives, such as improving the overall conditions of agriculture through conservation and maintenance of soil fertility, creation of a system of public information in the sphere of agriculture of the Russian Federation, the involvement of unions (associations) of agricultural producers to participate in the formulation of Government policy.

The content of the program makes no significant changes to the status quo. Since the ratio of the market power of companies representing different industries is not conducive to the proper functioning of agricultural enterprises, a new program should be considered as a document which allows an opportunity to improve the situation. For these and other reasons, there is a need for radical improvement of institutional conditions.

\section{Conclusion}

Thus, the analysis of the impact of institutional conditions on the development of agriculture, based on the example of one of the most developed agricultural regions of Russia, suggests that their current status does not allow the full implementation of public interests, nor or the long-term interests of the majority of private agricultural producers.

As a result of high price disparities between agricultural products (raw material for processing) and finished products after processing, the number of small businesses in agriculture - especially in the primary sector - is decreasing. Some businesses face bankruptcy, while others merge to form larger ones.

Among various economic factors, the redistribution of income between economic activities has the greatest impact on the state of agricultural organizations. Economic concentration in agriculture is expressed in the higher benefit, which contributes to the concentration of commercial and industrial capital.

Industrialization and technological progress in agro-holdings have substantially lowered transaction costs, and therefore increasingly enabled firms to outsource and relocate production to those locations where production costs are lowest. Analogue to conventional trade, this outsourcing can potentially bring about large efficiency gains that materialize in the form of increased competitiveness and thus higher growth of production. However, it is also clear that this process generates winners and losers. As a result, less competitive smaller producers are disappearing.

The analysis was carried out for the Belgorod region, which gives a model of industrialization in agriculture under Russian institutional settings. Comparing the social impact of the concentration of production, we can provide interesting new insights into the role of institutions and social policies for shaping and mitigating the impact of globalization.

Empirical evidence so far suggests that smaller agricultural producers are the losers from institutional transformations. However, our empirical studies generally use fairly aggregated data which allows an in-depth analysis of the social impact of this phenomenon.

Particularly smaller agricultural producers in Russia are arguably at risk of suffering higher economic insecurity, income losses, unemployment and social exclusion. As a result, despite the growth of the total population, the rural population shows a tendency to migrate to the city, where the wages are higher.

We have identified winners and losers from the institutional transformation process and have assessed to what extent concentration, and thus the industrialization of agricultural production, determine the individually experienced impact on different enterprises. Although wages at the aggregate level are central determinants of the social behavior of agricultural workers, our micro level approach allows us to look at other important factors too. It is now not only possible to look at aggregated wage effects, but also to assess the role of the concentration of agricultural production for individual economic security that manifests itself in fluctuations in annual income.

\section{References}

AGRICULTURE of the Belgorod Region. 2013. Belgorod, $138 \mathrm{p}$.

BROUSSEAU, E. - GARROUSTE, P. - RAYNAUD, E. 2011. Institutional Changes: Alternative Theories and Consequences for Institutional Design: The Dynamics of Institutions in Perspectives: Alternative Conceptions and Future Challenges. In: Journal of Economic Behavior and Organization, vol. 79, 2011, no. 1-2, pp. 3-19.

CHANG, H. J. - EVANS, P. 2005. 'The Role of Institutions in Economic Change', in G. Dymski and S. Da Paula (eds), Reimagining Growth. London : Zed Press, 2005. pp. 99-129.

GROMYKO, G. L. 2006. Theory of Statistics: a Training Manual. $2^{\text {nd }}$ ed., revised and expanded, Moscow, 2006. $476 \mathrm{p}$.

KOKOREV, R. 2008. Role of institutions for economic diversification in Russia, in: International Conference "Strengthening the integration of the economies in transition into the world economy through the diversification", Geneva 2-4 April 2008.

NORTH, D. 1990. Institutions, Institutional Change and Economic Performance, Cambridge, U.K. and N.Y. : Cambridge University Press.

PETRICK, M. 2008. Theoretical and methodological topics in institutional economics European agriculture, IAMO, Halle a.d.Saale, $81 \mathrm{p}$.

PODSHIVALENKO, G. R. 2006. Investments: a textbook and other $3^{\text {rd }}$ ed., revised and added: KnoRus, $200 \mathrm{p}$.

RUSSIA in figures. 2013. Moscow, $581 \mathrm{p}$.

\section{Contact address:}

Andrei Dorofeev, Belgorod State Agricultural Academy named after V. Gorin, Belgorod, Russia e-mail: interdaf@mail.ru, sergeysazonov10071986@ rambler.ru 